\title{
Prediction of the nutritive value of wet whole-crop sorghum silage according to the INRA feeding system by near-infrared spectroscopy
}

\author{
J. Kański', J.B. Pyś and P. Górka \\ University of Agriculture in Krakow, Department of Animal Nutrition and Feed Management \\ al. Mickiewicza 24/28, 30-059 Krakow, Poland
}

KEY WORDS: sorghum silage, NIRS, nutritive value

Received: 18 September 2012

Revised: 28 August 2013

Accepted: 9 September 2013

${ }^{1}$ Corresponding author:

e-mail: j.kanski@ur.krakow.pl

\begin{abstract}
The aim of the study was to determine the usefulness of near-infrared spectroscopy (NIRS) for direct estimation of energy, protein and fillunits as well as organic matter digestibility (OMD) for wet whole-crop sorghum silages according to the French feeding system for ruminants INRA (1988). Fifty-eight whole-crop sorghum silages ensiled alone or with the addition of wheat bran, rapeseed meal, or whole-crop maize were used to create a calibration data set. Wet samples of silage were scanned using a spectrophotometer $(570-1850 \mathrm{~nm})$. The spectral data were transformed to the first derivative. For scatter correction, standard normal variate and detrending methods were used. The calibration equations were developed using modified partial least squares regression. The accuracy of each equation was evaluated based on the coefficient of determination of calibration $\left(R^{2}\right)$, standard error of calibration, and standard error of cross validation (SECV). High $\mathrm{R}^{2}(>0.93)$ were shown for all parameters except OMD $\left(R^{2}=0.83\right)$. The highest SECV $(0.62)$ was observed for protein units, but all errors were within acceptable values. The results of the study suggest that NIRS may be used for direct prediction of nutritive value of sorghum silages in INRA system units. Furthermore, these results suggest that the NIRS technique may be successfully used for direct estimation of feed units for ruminants in wet silages.
\end{abstract}

\section{Introduction}

Accurate estimation of energy and protein value of feeds is important in ruminant nutrition. In most cases this requires the use of advanced feed unit systems. Among many available for ruminants, the feeding system developed by the French National Institute of Agronomic Research (INRA, 1988) is the most commonly used in Poland. In this system, as well as in other systems, energy and protein units are calculated based on the chemical composition of feeds. Chemical analysis and estimation of feed units are time consuming, and require advanced knowledge, which seems to be one of the limiting factors for their use in practice. Near-infrared spectroscopy (NIRS) is an alternative method allowing for substantial reduction of the time and costs of feed analysis. Furthermore, when NIRS is used, analysis can be done on fresh feeds (Cozzolino et al., 2006).

Sorghum has recently become a popular feed for ruminants in many countries (Oliver et al., 2004; Larraín et al., 2009), including Poland (Pyś et al., 
2008; Podkówka and Podkówka, 2011), mainly due to its high green yield that is less dependent on environmental conditions as compared with other feeds, e.g., maize, the most popular forage in feeding rations for dairy and beef cattle (Oliver et al., 2004; Staggenborg et al., 2008). Sorghum contains less protein and energy than maize, however (Oliver et al., 2004; Staggenborg et al., 2008; Podkówka and Podkówka, 2011). Ensiling of whole-crop sorghum in combination with other feeds was recently proposed as a method of increasing the nutritive value of sorghum silage for ruminants (Pyś et al., 2008).

The aim of this study was to evaluate the NIRS technique as a tool for estimating energy, protein and fill units, as well as organic matter digestibility (OMD), in wet sorghum silages according to the INRA (1988) feeding system for ruminants. For this purpose, a calibration data set was made from chemical analysis of whole-crop sorghum silages ensiled with or without other feeds.

\section{Material and methods}

Fifty-eight samples of whole-crops wet sorghum (Sorghum saccharatum, cv Sucrosorgo 506) silage, with or without the addition of other feeds, were used for this study. Detailed descriptions of the ensiling procedure and composition of silages were presented elsewhere (Pyś et al., 2008). Briefly, sorghum forage $\left(208 \mathrm{~g} \cdot \mathrm{kg}^{-1} \mathrm{DM}\right)$ was chopped (1.5$2.0 \mathrm{~cm}$ ) and ensiled with or without the addition (between 50 to $100 \mathrm{~g} \cdot \mathrm{kg}^{-1}$ ) of wheat bran, rapeseed meal, or whole-crop maize in 151 microsiloses. After 60 days, the microsiloses were opened, the contents removed and mixed thoroughly. Representative samples $(1 \mathrm{~kg})$ of the silages were collected, scanned, dried in a force-air oven at $55^{\circ}$ for $48 \mathrm{~h}$, ground through a 1-mm screen (Fritsch, IdarOberstein, Germany), and analysed for dry matter (DM), ash, crude protein (CP), ether extract (EE) and crude fibre (CF) contents using standard analytical procedures (procedures No. 934.01, 942.05, 976.05, 2003.05, 962.09 for DM, ash, CP, EE and $\mathrm{CF}$, respectively (AOAC, 2005).

Based on the chemical composition of silages, OMD and feed units according to the INRA (1988) system were calculated with PrevAlim software (part of INRAtion 3.3 software; INRAtion-PrevAlim, 2006) using the equations proposed by Baumont et al. (1999). The net energy value of silages was expressed in Feed Unit for lactation (UFL) and Feed Unit for maintenance and meat production (UFV). Protein truly digested in the intestine with nitrogen- and energy-limiting microbial synthesis in the rumen (PDIN and PDIE, respectively) was calculated assuming rumen protein degradation (degN) equal to $72 \%$ and intestinal protein digestion (dpi) equal to $70 \%$. Feed fill was expressed in Fill Unit for cattle (CFU), Fill Unit for lactating dairy cows (LFU) and Fill Unit for sheep (SFU). Calculated feed units were used as reference values for the NIRS method. Because INRA tables of feed composition and nutritive value do not present $\operatorname{degN}$ and dpi for whole-crop sorghum silage, characteristic values for whole-crop maize silage were used. This decision was made based on the same $\operatorname{degN}$ and dpi coefficients for sorghum and whole-crop maize green forage (INRA, 2007) and similar product fermentation, i.e. lactic acid, acetic acid, $\mathrm{pH}$ of whole-crop maize and sorghum silages (Filya, 2003; Podkówka and Podkówka, 2011). As a result, feed units obtained for sorghum silages used in this study may not necessarily reflect their true nutritive value, also due to the fact that sorghum silages with the addition of other feeds were used for the purposes of this study. Nevertheless, such an experimental procedure was sufficient to verify whether there is a correlation between near infrared spectra and reference values, and thus whether the NIRS technique can be used for prediction of the nutritive value of fresh sorghum silages,

Spectra of wet silages were collected in the visible and near infrared (NIR) regions in reflectance $(570-1850 \mathrm{~nm})$ at $2 \mathrm{~nm}$ intervals using a spectrophotometer (InfraXact, Foss, Hilleroed, Denmark). All silages were scanned twice. For each scan the cup was repacked with a new portion of the silage. A circular sample cup $(\varnothing=10 \mathrm{~cm})$ was rotated when spectra were collected. Reflectance data (average of two scans) were stored as logarithm of reciprocal of reflectance $\log (1 / \mathrm{R})$ using computer software ISIscan ver. 4 (ISIscan, 2009) on the hard drive of the computer. The samples were not ground before scanning, scatter correction methods were, therefore, used to correct the whole spectrum for particle size variation. For that purpose standard normal variate and detrend (SNVD) and multiplicative scatter correction (MSC) were tested (Barnes et al., 1989; Scotter, 2005). The mathematical treatment used in the transformation of the spectra was I derivative 1.4.4; where the first number indicates the order of derivative, the second number is the gap (nm) over which the derivative was calculated, and the third is the number (nm) used in smoothing (Murray, 1988; Shenk et al., 2008). Modified partial least squares (MPLS) regression was used to construct calibration equations (Shenk and Westerhaus, 1991). Due to the limited number of samples available, 
calibration models were developed and evaluated using cross validation (Dardenne et al., 2000). Cross validation was performed by splitting the calibration set into 6 groups ( 5 groups of 10 samples and 1 group of 8 samples). The set was not sorted. Each group of samples was removed from the 58 sample set and calibrations were calculated using the remaining samples while the excluded group of samples was predicted. The validation errors were combined into a standard error of cross validation (SECV) and the optimum number of terms was taken as the number resulting in the lowest prediction error. The resulting calibration equations between the chemical reference values and the NIR data were evaluated based on the coefficient of determination of calibration $\left(\mathrm{R}^{2}\right)$, standard error of calibration (SEC), and SECV. Calibration models with the highest $\mathrm{R}^{2}$ and the lowest SECV were considered the best. The Residual Predictive Deviation (RPD) coefficient, being a relationship between standard deviation (SD) of the analysed nutrient and SECV (SD/SECV ratio), was calculated for each calibration equation. The RPD calculated for NIR calibration indicates its quality (Sinnaeve et al., 1994). This ratio provides a comparison of performance of NIRS calibrations for all constituents irrespective of the units of chemical parameters. Manipulation on spectral data was done and calibration equations were performed using WinISI 4 software (WinISI, 2009). In the first step of the calculations, outliers were identified and deleted. A T test was used to eliminate reference values from the calibration set. The samples were considered outliers when reference versus predicted value (critical ' $\mathrm{T}$ ' value) was higher than 2.5.

\section{Results and discussion}

\section{Calibration set}

The chemical composition of the calibration set is presented in Table 1, whereas calculated energy, protein and fill units according to the INRA system are presented in Table 2. INRA tables of chemical composition and nutritive value (INRA, 2007) present only values for green forage sorghum bicolour, whereas values for sorghum silages are not available. According to available literature, UFL, UFV, PDIE and PDIN contents in whole-crop sorghum silages could be comparable to values presented in other studies (Oliver et al., 2004; Contreras-Govea et al., 2010; Podkówka and Podkówka, 2011). In this study, however, sorghum silage with the addition of between 50 to $100 \mathrm{~g} \cdot \mathrm{kg}^{-1}$ of different fresh feed supplementation was used. These combinations make direct comparison of the calibration data with
Table 1. Descriptive statistics for chemical parameters of wet whole sorghum silage samples used to develop the INRA feeding values $(n=58)$

\begin{tabular}{lrrlr}
\hline & Mean & Minimum & Maximum & SD \\
\hline $\mathrm{DM}, \mathrm{g} \cdot \mathrm{kg}^{-1}$ & 231.6 & 188.1 & 286.4 & 22.6 \\
Ash, $\mathrm{g} \cdot \mathrm{kg}^{-1} \mathrm{DM}$ & 78.8 & 52.0 & 100.3 & 10.6 \\
$\mathrm{CP}, \mathrm{g} \cdot \mathrm{kg}^{-1} \mathrm{DM}$ & 118.7 & 85.1 & 172.6 & 28.3 \\
$\mathrm{CF}, \mathrm{g} \cdot \mathrm{kg}^{-1} \mathrm{DM}$ & 273.9 & 205.0 & 330.5 & 27.7 \\
$\mathrm{EE}, \mathrm{g} \cdot \mathrm{kg}^{-1} \mathrm{DM}$ & 28.7 & 18.2 & 44.4 & 5.4 \\
$\mathrm{OM}, \mathrm{g} \cdot \mathrm{kg}^{-1} \mathrm{DM}$ & 921.2 & 899.7 & 948.0 & 10.6 \\
\hline
\end{tabular}

DM - dry matter; CP - crude protein; CF - crude fibre; EE - ether extract; OM - organic matter; SD - standard deviation

Table 2. Nutrition value of sorghum silage calculated according to INRA system

\begin{tabular}{lcccc}
\hline & Mean & Minimum & Maximum & SD \\
\hline UFL, $\mathrm{kg}^{-1} \mathrm{DM}$ & 0.86 & 0.82 & 0.94 & 0.03 \\
UFV, $\mathrm{kg}^{-1} \mathrm{DM}$ & 0.76 & 0.71 & 0.84 & 0.03 \\
PDIN, g $\cdot \mathrm{kg}^{-1} \mathrm{DM}$ & 74 & 52 & 107 & 18 \\
PDIE, g $\cdot \mathrm{kg}^{-1} \mathrm{DM}$ & 70 & 62 & 82 & 6 \\
$\mathrm{SFU}, \mathrm{kg}^{-1} \mathrm{DM}$ & 1.29 & 1.28 & 1.35 & 0.02 \\
$\mathrm{LFU}, \mathrm{kg}^{-1} \mathrm{DM}$ & 1.24 & 1.10 & 1.38 & 0.07 \\
CFU, $\mathrm{kg}^{-1} \mathrm{DM}$ & 1.25 & 1.11 & 1.38 & 0.07 \\
OMD, \%, $\mathrm{kg}^{-1} \mathrm{DM}$ & 71.14 & 68.91 & 74.65 & 1.16
\end{tabular}

UFL - feed unit for milk production; UFV - feed unit for maintenance and meat production; PDIN - protein truly digestible in the intestine with nitrogen limiting factor for microbial synthesis in the rumen; PDIE - protein truly digestible in the intestine with energy limiting factor for microbial synthesis in the rumen; SFU - fill unit for sheep; LFU - fill for lactating cow unit; CFU - fill unit for cattle; OMD - organic matter digestibility

the nutritive value of whole-crop sorghum silage presented in other studies somewhat less informative. Nonetheless, because of the practicalities of such an ensiling method (Pyś et al., 2008), and the fact that the combination of sorghum with other feeds provided broader variability in feed value ranges, their application in developing a whole-crop sorghum silage NIRS calibration is justified.

\section{NIRS predictions}

The SNVD spectral data correction improved the accuracy of estimation as compared with MSC. A similar positive effect on accuracy of estimation was obtained when spectral data was transformed to the first derivative with mathematical treatment 1.4.4 (Table 3) and in combination with MPLS, which is considered the best regression method for purposes of the NIRS technique (Shenk and Westerhaus, 1991). In the first steps of the calculations, outliers were identified and removed from the calibration set (Figures 1 to 4), which further improved the accuracy of estimation. 
Table 3. Summary of the NIR cross validation statistics to measure $\mathrm{DM}, \mathrm{OMD}$ and INRA parameters in wet whole sorghum silage (I derivative, $S N V D$ )

\begin{tabular}{llllll}
\hline & $\mathrm{n}$ & $\mathrm{R}^{2}$ & $\mathrm{SEC}$ & $\mathrm{SECV}$ & $\mathrm{RPD}$ \\
\hline $\mathrm{DM}, \%$ & 54 & 0.97 & 0.336 & 0.392 & 5.72 \\
OMD, \% & 56 & 0.83 & 0.441 & 0.484 & 2.40 \\
UFL & 56 & 0.97 & 0.004 & 0.005 & 5.06 \\
UFV & 56 & 0.97 & 0.004 & 0.005 & 5.09 \\
PDIN, g & 55 & 0.99 & 0.508 & 0.622 & 7.84 \\
PDIE, g & 57 & 0.97 & 0.410 & 0.533 & 4.69 \\
SFU & 55 & 0.96 & 0.005 & 0.006 & 4.64 \\
LFU & 56 & 0.93 & 0.003 & 0.004 & 3.33 \\
CFU & 56 & 0.94 & 0.003 & 0.004 & 3.48 \\
\hline
\end{tabular}

$\mathrm{R}^{2}$ - coefficient of determinations; SEC - standard error of calibration; SECV - standard error of cross validation; RPD coefficient (calculated as SD/SECV for fresh silage)

Table 4. The statistical data for verification of calibration equations of wet whole sorghum silage

\begin{tabular}{lrlll}
\hline & Mean $^{1}$ & SD & $\begin{array}{l}\text { SEC, } \\
\% \text { of mean }\end{array}$ & $\begin{array}{l}\text { SECV, } \\
\% \text { of mean }\end{array}$ \\
\hline DM , g & 22.93 & 2.03 & 1.47 & 1.71 \\
OMD, \% & 71.10 & 1.08 & 0.62 & 0.68 \\
UFL & 0.20 & 0.02 & 1.97 & 2.53 \\
UFV & 0.17 & 0.02 & 2.25 & 2.71 \\
PDIN, g & 16.82 & 4.70 & 3.02 & 3.70 \\
PDIE, g & 16.16 & 2.42 & 2.53 & 3.30 \\
SFU & 0.30 & 0.02 & 1.65 & 1.92 \\
LFU & 0.29 & 0.01 & 1.19 & 1.33 \\
CFU & 0.29 & 0.01 & 1.18 & 1.36 \\
\hline
\end{tabular}

1 the mean calculated without outliers; SD - standard deviation; SEC - standard error of calibration expressed as percent of the mean; SECV - standard error of cross validation expressed as percent of the mean

The high $\mathrm{R}^{2}$ for the best calibration equations confirmed the high correlation between infrared spectra characteristics and nutritive values calculated according to the INRA system. For protein and energy content, the $\mathrm{R}^{2}$ were higher than 0.97. Somewhat lower, but still high, $\mathrm{R}^{2}$ were obtained for equations for SFU, LFU and CFU. The lowest correlation was obtained for OMD (Table 4). Cozzolino et al. (2006) also showed low correlation between NIR spectra and OMD. The result obtained in our study was much higher than that presented by Cozzolino et al. (2006) for whole-crop maize silage, equaling 0.40 . The low correlation between spectra data and OMD is difficult to explain, but in the current study it could be a result of the indirect (mathematical) OMD calculation and the mixing of sorghum silage with other feeds.

SEC and SECV for all values were low (Table 3 ), indicating good accuracy of nutritive value estimations according to the INRA system (Figures 1 to 4). Assessment of the quality of calibration equations based on RPD (Table 3 ) assumes that only equations with an RPD higher than 3 could be used for routine analytical purposes (Park et al., 1998; Williams, 2001). According to Fearn (2002), an RPD higher than 2.5 can also classify equations for routine analytical use. In this study, all equations, except for OMD, met the above recommendation.

The highest RPD was calculated for PDIN. Very high values were obtained for both energy values (UFL and UFV) and DM content. It seems that the lowest RPD values obtained for OMD in this study are rather a result of the low SD (narrow range) of the mean of silages used for the calibration set rather than high errors of estimation and could be acceptable for this type of analysis (Smith, 2010).

Accuracy of estimation was also determined based on SEC expressed as a percent of mean content, calculated without outliers (Table 4). When considering mean nutrient content, the highest error was observed for PDIN and PDIE ( $\mathrm{SEC}_{\% \text { mean }}=$ $3.02 \%$ and $2.53 \%$, respectively), whereas OMD estimation was the most accurate $\left(\mathrm{SEC}_{\% \text { mean }}=0.62 \%\right.$; Table 4). Calculated SECV (Table 3) were slightly higher than SEC. The highest SECV were observed for PDIN and PDIE (0.622 and 0.533, respectively), equaling $3.70 \%$ and $3.30 \%$ of the mean for the calibration set $\left(\mathrm{SECV}_{\% \text { mean }}\right)$, which was similar to what was obtained for SEC. It is worth noting, however, that the error of estimation was greatly affected by outliers, which were used in the step of calibration equation verification. Figures 1 to 4 graphically present samples used for estimation of energy (UFL and UFV) and protein (PDIN and PDIE) units. Outliers are indicated by an ' $x$ '. The high precision of estimation of DM content and OMD was confirmed by the low SECV (0.392 and 0.484, respectively), which accounted for $\mathrm{SECV}_{\% \text { mean }}=1.71 \%$ and $\mathrm{SECV}_{\% \text { mean }}=0.68 \%$ for DM and OMD, respectively. Similar values were obtained by Park et al. (1998). Errors obtained for fill units were also low and ranged between $\mathrm{SECV}_{\% \text { mean }}=1.33 \%$ and $1.92 \%$ for LFU and SFU, respectively.

The accuracy of analysis using NIRS depends on many factors, among which sample preparation plays an important role (Alomar et al., 1999). The highest accuracy of estimation is obtained when dried and ground $(0.3-1.0 \mathrm{~mm})$ samples are used, mainly due to improved homogeneity of the sample (Osborne et al., 1993). Analysis on fresh forages, especially justified from the practical point of view, may substantially speed up achieving results. Reeves and Blosser (1991) and Griggs et al. (1999) suggest that accuracy of analysis performed on wet 


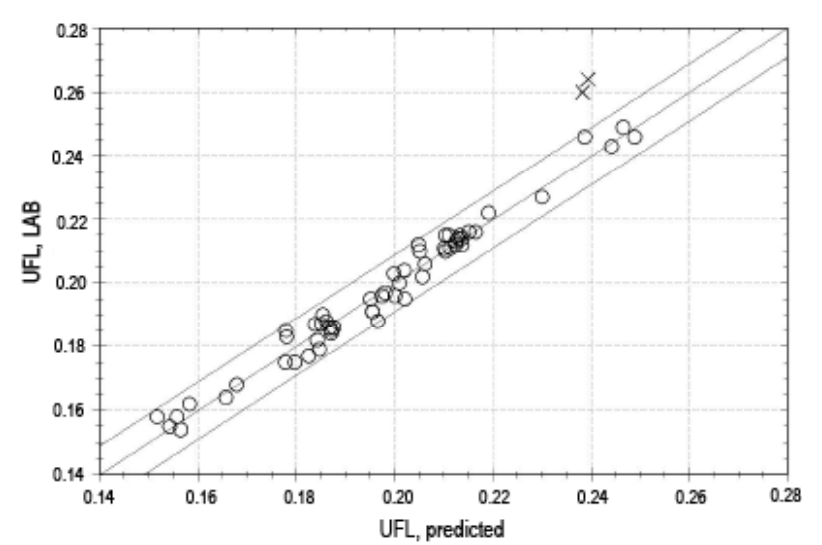

Figure 1. The relationship between calculated UFL (UFL LAB) and estimated by NIRS (UFL predicted) in wet whole crop sorghum silage (UFL $\cdot \mathrm{kg}^{-1} ;$ I derivative, SNVD), $\mathrm{x}$ - outliers

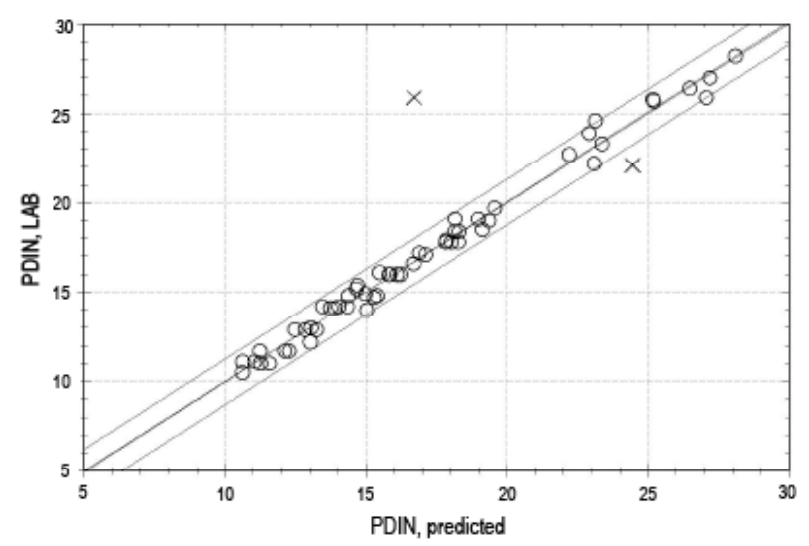

Figure 3. The relationship between calculated PDIN (PDIN LAB) and estimated by NIRS (PDIN predicted) in wet whole crop sorghum silage $\left(\mathrm{g} \cdot \mathrm{kg}^{-1} ;\right.$ I derivative, SNVD), $\mathrm{x}$ - outliers

material is lower as compared with analysis on dried and ground samples. Furthermore, fresh plant material contains above $60 \%$ of water, which may also negatively affect precision of estimation (Shenk et al., 2008). This is because carbohydrates, such as sucrose, starch and cellulose, have -OH functional groups that absorb at wave lengths similar to water (Osborne and Douglas, 1981; Workman and Weyer, 2008), and thus the presence of water in the sample affects interpretation of the spectra of other components. Other factors, such as particle size of material, may also influence the accuracy of NIR calibrations (Lovett et al., 2005), mainly due to lack of homogeneity of the sample. This is of particular importance when analysis is performed on unground samples such as whole-crop silages, including those used in this study.

The accuracy of the obtained results using NIRS also depends on the accuracy of the reference method (Osborne et al., 1993). Although silages were subjected to chemical analysis, feed unit contents were calculated, which means that

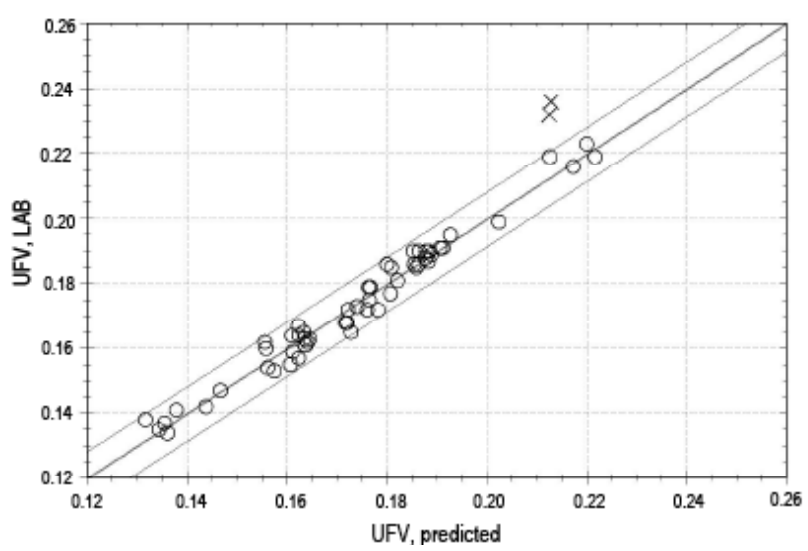

Figure 2. The relationship between calculated UFV (UFV LAB) and estimated by NIRS (UFV predicted) in wet whole crop sorghum silage (UFV $\cdot \mathrm{kg}^{-1}$; I derivative, SNVD), $\mathrm{x}$ - outliers

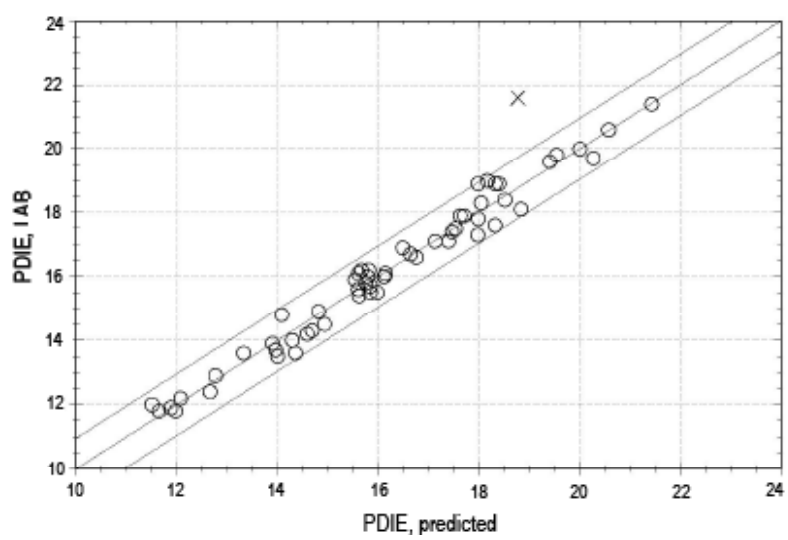

Figure 4. The relationship between calculated PDIE (PDIE LAB) and estimated by NIRS (PDIE predicted) in wet whole crop sorghum silage (g. $\mathrm{kg}^{-1} ;$ I derivative, SNVD), $\mathrm{x}$ - outliers

the reference method was obtained indirectly, and this may affect the accuracy of estimation.Taking this into account, as well as the fact that analysis was done on wet material, the results of estimation obtained in this study can be considered very satisfying.

\section{Conclusions}

To our knowledge, this is first study in which an attempt to use NIRS for direct estimation of feeding values according to the INRA feeding system in wet whole-crop silages was made. The results suggest that NIRS can be used for direct estimation of nutritive value of wet sorghum silages in INRA system units.

\section{References}

Alomar D., Montero R., Fuchslocher R., 1999. Effect of freezing and grinding method on near infrared reflectance (NIR) spectra variation and chemical composition of fresh silage. Anim. Feed Sci. Tech. 78, 57-63 
AOAC, 2005. Association of Official Analytical Chemists, Official Methods of Analysis. $18^{\text {th }}$ Edition. Rev. 2, 2007. Gaithersburg, MA

Barnes R.J., Dhanoa M.S., Lister S.J., 1989. Standard normal variate transformation and detrending of near infrared diffuse reflectance spectra. Appl. Spectrosc. 43, 772-777

Baumont R., Champciaux P., Agabriel J., Andrieu J., Aufrère J., Michalet-Doreau B., Demarquilly C., 1999. Une démarche intégrée pour prévoir la valeur des aliments pour les ruminants: PrévAlim pour INRAtion. INRA Prod. Anim. 12, 183-194

Contreras-Govea F.E., Marsalis M.A., Lauriault L.M., Bean B.W., 2010. Forage sorghum nutritive value: A review, Online. Forage and Grazinglands. http://dx.doi.org/10.1094/FG-20100125-01-RV

Cozzolino D., Fassio A., Fernandez E., Restaino E., La Manna A., 2006. Measurement of composition in wet whole maize silage by visible and near infrared reflectance spectroscopy. Anim. Feed Sci. Tech. 129, 329-336

Dardenne P., Sinnaeve G., Baeten V., 2000. Multivariate calibration and hemometrics for near infrared spectroscopy: which method? J. Near Infrared Spectrosc. 8, 229-237

Fearn T., 2002. Assessing calibrations: SEP, RPD, RER and R². NIR news. 13 (6), 12-14

Filya I., 2003. The effect of Lactobacillus buchneri and Lactobacillus plantarum on the fermentation, and ruminal degradability of low dry matter corn and sorghum silages. J. Dairy Sci. 86, 3575-3581

Griggs T.C., Lobos K.B., Kingery P.E., 1999. Digestibility analysis of undried, unground, and dry ground herbage by near-infrared reflectance spectroscopy, Crop Sci. 39, 1164-1170

INRA, 1988. Alimentation Des Bovins, Ovins \& Caprins. R. Jarrige (Editor). INRA \& Quae. Paris, pp. 471

INRA, 2007. Alimentation des Bovins, Ovins et Caprins, Besoins des Animaux - Valeurs des Aliments, Tables INRA 2007. Editions Quae (France), pp. 307

INRAtion-PrevAlim, 2006. Computer software ver, 3,2 Inra Educagri Editions. Bp 87999 F 21079 Dijon Cedex (France)

ISIScan 4, 2009. Infrasoft International LLC, 1362 South Atherton St. State College, PA 16801 (USA)

Larraín R.E., Schaefer D.M., Arp S.C., Claus J.R., Reed J.D., 2009. Finishing steers with diets based on corn, high-tannin sorghum, or a mix of both: Feedlot performance, carcass characteristics, and beef sensory attributes. J. Anim. Sci. 87, 2089-2095

Lovett D.K., Deaville E.R., Givens D.I., Finlay M., Owen E., 2005. Near infrared reflectance spectroscopy (NIRS) to predict biological parameters of maize silage: effects of particle comminution, oven drying temperature and the presence of residual moisture. Anim. Feed Sci. Tech.120, 323-332

Murray I., 1988. Aspects of the interpretation of NIR spectra. In: C.S. Creaser, A.M.C. Davies (Editors). Analytical Applications of Spectroscopy, Royal Society of Chemistry, London, 9-20

Oliver A.L., Grant R.J., Pedersen J.F., O'Rear J., 2004. Comparison of brown midrib-6 and -18 forage sorghum with conventional sorghum and corn silage in diets of lactating dairy cows. J. Dairy Sci. 87, 637-644

Osborne B.G., Fearn T., Hindle P.H., 1993. Practical NIR spectroscopy with applications in food and beverage analysis, Longman Sci \& Technical. $2^{\text {nd }}$ Edition, pp. 227

Osborne B.G., Douglas S., 1981. Measurement of the degree starch damage in flour by near infrared reflectance analysi. J. Sci. Food Agr. 32, 328-332

Park R.S., Agnew R.E., Gordon F.J., Steen R.W.J., 1998. The use of near infrared reflectance spectroscopy (NIRS) on undried samples of grass silage to predict chemical composition and digestibility parameters. Anim. Feed Sci. Tech. 72, 155-167

Podkówka Z., Podkówka L., 2011. Chemical composition and quality of sweet sorghum and maize silages. J. Cent. Europ. Agr. 12, 294-303

Pyś J., Borowiec F., Karpowicz A., 2008. Effect of bacterial-chemical additive and juice absorbents on chemical composition and aerobic stability of sweet sorghum silages. (in Polish) In: T. Michalski (Editor). Agrotechnological Problems and Maize and Sorghum Utilization. University of Life Sciences Poznań (Poland), pp. 242-244

Reeves III J.B., Blosser T.H., 1991. Near infrared spectroscopic analysis of undried silages as influenced by sample grind, presentation method, and spectral region. J. Dairy Sci. 74, 882-895

Scotter C.N.G., 2005. Infrared Spectroscopy, Infra-Red. Elsevier, $415-426$

Shenk J.S., Westerhaus M.O., 1991. Population definition, sample selection and calibration procedures for near infrared reflectance spectroscopy. Crop Sci. 3, 469-474

Shenk J.S., Workman J.J.Jr, Westerhaus M.O., 2008. Application of NIR Spectroscopy to Agricultural Products. In: Handbook of Near-Infrared Analysis, 3rd Edition, In: D. Burns, E. Ciurczak (Editors). CRC Press Taylor \& Francis Group, 6000 Broken Sound Parkway NW, Boca Raton, FL (USA), pp. 347-397

Sinnaeve G., Dardenne P., Agneessens R., Biston R., 1994. The use of near infrared spectroscopy for the analysis of fresh grass silage. J. Near Infrared Spectrosc. 2, 79-84

Smith S.J., 2010. Evaluation of analytical data. In: S. Nielsen (Editor). Food Analysis. Springer Science Business Media. New York, pp. 53-67

Staggenborg S.A., Dhuyvetter K.C., Gordon W.B., 2008. Grain Sorghum and Corn Comparisons: Yield, Economic, and Environmental Responses. Agron. J. 100, 1600-1604

Williams P.C., 2001. Implementation of near infrared technology. In: P.C. Williams K.H. Norris (Editors). Near Infrared Technology in the Agricultural and Food Industries. American Association of Cereal Chemist, St, Paul, Minnesota, pp. 145-169

WinISI 4, 2009. Infrasoft International LLC, 1362 South Atherton St, State College, PA 16801 (USA)

Workman Jr. J., Weyer L., 2008. Practical Guide to Interpretive NearInfrared Spectroscopy. CRC Press Taylor \& Francis Group, 6000 Broken Sound Parkway NW, Suite 300 Boca Raton, FL (USA), pp. 332 